\title{
Effects of Reading Strategy and Dictionary Instruction in an \\ Undergraduate Foreign \\ Language Reading \\ Comprehension Group
}

$\begin{array}{ll}\begin{array}{l}\text { Efectos de la } \\ \text { enseñanza }\end{array} & \begin{array}{l}\text { Efeitos do ensino } \\ \text { explícito } \\ \text { do uso do dicionário } \\ \text { explícita del uso }\end{array} \\ \text { de diccionario y } & \text { e estratégias de } \\ \text { estrategias de } & \text { leitura em um curso } \\ \text { lectura en un curso } & \text { de compreensão } \\ \text { de comprensión de } & \text { de leitura de língua } \\ \text { lectura en lengua } & \text { estrangeira em } \\ \text { extranjera en } & \text { prégraduação } \\ \text { pregrado } & \end{array}$

Sergio Alonso Lopera Medina* Orcid: https://orcid. org/0000-0003-2773-0890

* Member of eale research group, Escuela de Idiomas. Universidad de Antioquia. Medellín, Antioquia. Contact: sergio.lopera@udea.edu.co

\section{(c) $\underset{\mathrm{BY}}{\mathrm{B}(\mathrm{NG})}$}

Lopera, S. A. (2019).

Effects of Reading Strategy and Dictionary Instruction in an Undergraduate Foreign Language Reading Comprehension Group.

Folios, 50, 127-138.
Artículo recibido $3 \cdot 03 \cdot 2018$

Artículo aprobado $25 \cdot 01 \cdot 2019$ 


\section{Abstract}

This article ${ }^{1}$ reports the effects of the integration of dictionary use and the reading strategy approach in a foreign language reading comprehension course. A case study was used as a research method, and three instruments helped gather data: a reading comprehension test, field notes, and an interview. Fifteen undergraduate students from a public university in Medellin, Colombia, participated in the study. Improvement in reading, metacognitive awareness, and selective use of dictionary were found as part of positive effects. In contrast, tiredness appears to be as the negative effect. Conclusions suggest that both the reading strategy approach and the selective use of dictionary are a good combination to integrate into a foreign language reading course.

\section{Keywords}

dictionary use; language teaching; reading strategy approach

\section{Resumen}

Este artículo informa los efectos de la integración del uso del diccionario y el enfoque de estrategias de lectura en un curso de comprensión de lectura en lengua extranjera. Como método de investigación se utilizó el estudio de caso y se emplearon tres instrumentos para recolectar la información: una prueba de comprensión de lectura, notas de campo y una entrevista. En el estudio participaron quince estudiantes de pregrado de una universidad pública de Medellín (Colombia). La mejoría en la lectura, la conciencia metacognitiva y el uso selectivo del diccionario se encontraron como parte de los efectos positivos. En contraste, el cansancio aparece como el efecto negativo. Las conclusiones sugieren que tanto el enfoque de estrategia de lectura como el uso selectivo del diccionario son una excelente combinación para integrar en un curso de lectura en lengua extranjera.

\section{Palabras clave}

uso de diccionario; enseñanza de idiomas; enfoque de estrategias de lectura

\section{Resumo}

Este artigo apresenta os efeitos da integração do uso do dicionário e da abordagem de estratégias de leitura em um curso de compreensão de leitura de língua estrangeira. Como método de pesquisa, utilizou-se o estudo de caso e foram utilizados três instrumentos para coleta das informações: teste de compreensão de leitura, notas de campo e entrevista. 15 estudantes de pre-graduação de uma universidade pública participaram do estudo. Melhoria na leitura, consciência metacognitiva e uso seletivo do dicionário foram os elementos encontrados como efeitos positivos. Em contraste, a fadiga aparece como efeito negativo. As conclusões indicam que tanto a abordagem da estratégia de leitura quanto o uso seletivo do dicionário são uma boa combinação para integrar um curso de leitura de língua estrangeira.

\section{Palavras-chave}

ensino de línguas; uso de dicionário; abordagem de estratégias de leitura

1 This article is a post product of the research project Effects of the modalities of instruction face-to-face and web-based distant in Reading comprehension in English in the graduate programs at Universidad de Antioquia, funded by Comité para el Desarrollo de la Investigación CODI and carried out between January 2009 and September 2011. 


\section{Introduction}

Foreign language or second language teachers may have different ideas about the effectiveness of using a dictionary when reading. However, research has demonstrated that dictionaries help language students in their learning process (Chen, 2012; Shen, 2013), especially in vocabulary expansion and in eventual reading comprehension (Knight, 1994; Luppescu and Day, 1993). Moreover, students now have the option not only to use a paper dictionary in class, but also online dictionaries, online translators and Google translator, and this has affected the way of learning (Jin and Deifell, 2013). Thus, the emergence of online resources has to change the way language educators teach and how students learn (Blake, 2008). However, Miller (1999) points out that dictionaries present important information of a word but the definitions are not contextualized, and language participants need to be trained for the correct use of a dictionary. While some teachers may let students use the dictionaries when they come across an unfamiliar word, others ask students to apply a reading strategy to infer meaning. Jin and Deifell (2013) state that successful learners tend to implement different tactics and the idea of "to use or not to use" the dictionary is an academic issue that needs to be considered. This article reports the effects of the integration of dictionary use and the reading strategy approach in a foreign language reading comprehension course for undergraduate students at a public university in Medellín, Colombia. It starts with the literature review that covers the use of dictionaries in learning a foreign language, types of dictionaries, selective dictionary use, online dictionaries and resources, and the reading strategy approach. Then, the methodology and the research context are presented. Finally, the findings and conclusions are outlined.

\section{Research about dictionaries}

Some researchers support that dictionaries can help language students in reading (Bogaards, 1998; Chen, 2012; Shen, 2013; Summers, 1988). Studies have shown that dictionary use helps learners improve reading comprehension and might lead to lexical improvement. Researchers have found that students score better on post reading comprehension and vocabulary tests due to the use of dictionaries (Summers, 1988). They have also proved that the dictionary use may lead to lexical retention (Peters, 2007; Pulido, 2007; Robinson, 2003) and when readers look up a word in a dictionary, they pay more attention to the word, helping them retain it. In another study, Mokhtar, Mohd, and Omar (2013) found that dictionary consultation helps Net Generation students acquire vocabulary more successful. Finally, Liu (2014) reports that students show efficiency when teachers integrate the dictionary use strategy training.

On the other hand, some language teachers state that the use of dictionaries while reading may lead to inefficient learning for different reasons (Bensoussan, Sim and Weiss, 1984; Hunt, 2009). The first reason is time as studies have shown that students take more time when they use a dictionary to complete a task (Knight, 1994; Luppescu and Day, 1993). Besides, the time readers take to look up words in a dictionary interferes with their short-term memory leading to prevent readers from focusing on the text. A second reason is the lack of improvement. Knight (1994), and Bensoussan, Sim, and Weiss (1984) have demonstrated that more proficient learners do not show significant improvement because they use extra-time inefficiently to find the meaning of some words in a dictionary. A third reason has to do with the right meaning of a word. Students sometimes do not locate the proper dictionary entry, leading to misunderstanding (Tang, 1997; Hunt, 2009).

\section{Different types of dictionaries}

Dictionaries for language learners come either in printed form or electronic form and printed dictionaries can be monolingual, bilingual, and bilingualized. Nation (2001) suggests that monolingual dictionaries are for readers that have at least 2,000 words of vocabulary to understand definitions. These dictionaries have definitions, information, 
and examples in the target language. On the other hand, bilingual dictionaries provide the meaning of a word in two languages, one including the user's native language. These dictionaries usually define a word in an easy way to understand, even for a beginner.

Regarding the bilingualized dictionary, it has the combination of monolingual and bilingual ones: the information of a monolingual dictionary and the translation of the headword (Nation, 2001). Finally, studies on the use of monolingual and bilingual dictionaries have proved that learners prefer to use bilingual dictionaries (Laufer and Hadar, 1997; Schmitt, 1997). However, researchers recommend bilingual dictionaries for beginners and intermediate-level learners, and monolingual dictionaries for advanced ones.

As it was mentioned above, the format of a dictionary not only comes in paper but also in electronic form. Pocket electronic dictionaries, online dictionaries, and marginal glosses are available for students. Electronic dictionaries are easy to use, and users save time. Research has shown that electronic dictionary users take less time to look up a word than paper dictionary users (Koyama and Takeuchi, 2004). However, the number of lookups did not show a better reading improvement in both users.

\section{Selective dictionary use}

Studies have shown advantages and disadvantages to use a dictionary when reading, but a concern arises about the use of dictionaries in academic contexts. Grabe and Stoller (2004) suggest that language teachers should ask their students to pay attention to words that are related to the main ideas of a reading. Indeed, some words are more important than others in terms of reading comprehension. For instance, an unknown word which is presented in a heading or subtitle might be more significant than an unknown word that appears in the middle of a paragraph. If a reader obtains the general idea of a passage without knowing a couple of words, it could be a good idea not to use the dictionary for those unknown words.
As a result, it is advisable to use the dictionary in a selective form.

Prichard (2008) defines selective dictionary use as "looking up words that cannot be readily guessed from context and that are either useful to learn or relevant to the main points of the passage or the tasks at hand" (p. 220). This use might help learners improve reading comprehension and might also lead to vocabulary development as well as efficient use of study time. The author concludes that selective dictionary use might mean looking up enough words to help reading comprehension. Finally, Thornbury (2002) adds that dictionary users also need some skills when they use the dictionary: analyzing the different meanings of a word, using synonyms or antonyms to find the right intended sense, decoding the abbreviations in the entries, and recognizing features of dictionary design.

\section{Ways to use the dictionary}

There are two ways of using the dictionary: receptive use and productive use (Nation, 2001). The former deals with checking the signification of an unknown word, finding the correct entry, choosing the correct sub-entry, and applying the meaning of the context of the reading. The latter has to do with finding the wanted word, checking the constraints on the use of the word, and finding out about the grammar and collocation of the word.

\section{Online dictionaries and resources}

Researchers have investigated if online dictionaries help language learners and have concentrated on vocabulary learning and writing (Stockwell, 2007). Laufer and Hill (2000) found that electronic dictionaries helped students in incidental vocabulary learning, due to the contextual information as dictionaries include translations, synonyms, as well as, audio pronunciation. Moreover, CárdenasClaros and Gruba (2009) affirm that when online dictionaries have more contexts of usage, more successful learning is seen. However, the language level of students plays an essential role in learning. Beginners are confused by the multiple definitions 
online dictionaries provide, but advanced learners benefit, as the dictionaries give more details of language use (Loucky, 2010).

As it was stated above, students now have the option to use online translators in class and Google translator is one of the tools for learners. Then, translation becomes an important element that helps the reader to understand the text. Al-Musawi (2014) supports that translation is a useful strategy as it helps learners develop their communicative competence because it assists students in identifying semantic relationships, discourse values, and structure information of sentences. Based on different authors, Al-Musawi (2014) lists a set of strategic use of translation in language learning:

- Enhancing English skills: translation facilitates comprehension, increases motivation, and leads to learn vocabulary. It also helps memorize words.

- Linking the words: making an effective crosslingual comparison is helpful for language learners. The strategy to connect the new word to the student's mother tongue is beneficial for students.

- Using learning and technology aids: paper dictionaries, online dictionaries, online translators, and internet help students learn a language. When students use online tech, they are applying a constructive approach.

- Interacting with other peers: translation is considered a social strategy and students share their translations with their peers. As a result, peer correction is seen in classrooms.

On the other hand, Cook (2010) sees translation as a poor learning strategy as the best way to learn a language is in communicative contexts.

\section{The reading strategy approach}

Since second language readers tend to depend so much on the text and rely on deciphering word by word and translation (Hunt, 2009), the application of an explicit teaching approach in reading becomes an essential aspect in language learning.
The idea of helping readers become more skillful is a must, and the reading strategy approach is one of the options. Block (1986) states that the reading strategy approach involves a set of methods and techniques that readers use to achieve success in reading. Reading strategies also entail a conscious mental process to accomplish specific reading tasks (Cohen, 1990), and with this approach language readers increase their confidence and motivation and may have faster access to reading materials (Mikulecky and Jeffries, 2004).

Researchers usually divide reading strategies into two main categories: cognitive and metacognitive (Block, 1986; Carrell, Pharis, and Liberto, 1989; Davis and Bistodeau, 1993; Grabe and Stoller, 2002, 2004). Cognitive strategies help readers construct meaning from the text, and they can use two kinds of sub-strategies: bottom-up and top-down. When readers use bottom-up strategies, they start processing information at the sentence level. For instance, they pay attention to the meaning and grammatical category of a word, syntax, details of a text, among others. Readers then check how this information fits into the whole test leading to use top-down strategies such as prediction, skimming, background knowledge, or getting the gist of a text (Aebersold and Field, 1997; Barnett, 1988; Grabe and Stoller, 2002;). Regarding metacognitive strategies, they help monitor or regulate cognitive strategies (Devine, 1993; Flavell, 1981). Checking to solve a problem, planning a move in a reading, monitoring the effectiveness of an action are examples of this category. The combination of cognitive and metacognitive strategies helps language readers become more successful.

\section{Methodology}

An exploratory case study was used (Creswell, 2007; Yin, 2003) as research method to explore the use of reading strategies and dictionaries after a pedagogical intervention. The course teacher took the role; therefore, he gathered data and analyzed the effects of the reading strategy use and dictionary use in his reading comprehension group (Freeman, 1998). 
The research question that guided his inquiry was: What are the effects of reading strategy and dictionary instruction in an undergraduate foreign language reading comprehension group?

\section{Data collection instruments}

The teacher-researcher used three instruments to gather data: two different reading comprehension tests (pre and post test), field notes, and an interview. Each reading test contained two paragraphs with 18 multiple choice questions which included the subskills of scanning, topic, main ideas, guessing word meaning, inference, and referents. Students could use the dictionary and had 90 minutes to respond to the test. It is worth noting that the test was implemented at the beginning and end of the reading course. The second tool included the field notes and self-reflection the teacher tracked during his pedagogical intervention. He took notes about the strategies students applied in the classroom as well as his reflections about the students' performance. Finally, the teacher interviewed the students individually to gather data about their use of reading strategies, dictionary use, and the improvements and difficulties with the course.

\section{Context}

Participants were undergraduate students from the Faculty of Chemistry at Universidad de Antioquia, Medellín-Colombia. They were in their fourth or fifth semester of chemistry, food or pharmaceutical studies and the English reading comprehension I was a compulsory course of the program. This course was offered during the second semester in 2016 and taken by 15 students who participated in the research. Participants were 13 women and two men and their age ranged between 19 and 22. Regarding their backgrounds in language learning, the students had only received instruction in their high schools. The course was taught in Spanish, as the students did not feel confident to interact in English, but the reading texts and exercises were in English.

The objective of the course was to prepare students in the use of reading strategies for general reading. The course lasted 80 hours and students attended it twice a week, two hours each class session. The course comprehended six units as table 1 shows.

Table 1. Organization of the reading comprehension course.

\begin{tabular}{|c|c|c|}
\hline Unit & Name & Topics \\
\hline 1 & $\begin{array}{l}\text { Grammar aspect } \\
\text { in reading } \\
\text { comprehension }\end{array}$ & $\begin{array}{l}\text { Sentence structure, } \\
\text { verb tenses, modal } \\
\text { verbs, comparison, } \\
\text { superlatives, main } \\
\text { sentence, second } \\
\text { sentences, possessive, } \\
\text { passive voice, simple } \\
\text { and complex sentences, } \\
\text { connectors. }\end{array}$ \\
\hline 2 & Dictionary use & $\begin{array}{l}\text { Application of exercises } \\
\text { to use the dictionary. }\end{array}$ \\
\hline 3 & $\begin{array}{l}\text { Guessing word } \\
\text { meaning by its } \\
\text { structure }\end{array}$ & $\begin{array}{l}\text { Guessing the word } \\
\text { meaning by its affixes }\end{array}$ \\
\hline 4 & Referents & $\begin{array}{l}\text { Application of } \\
\text { exercises in sentences, } \\
\text { paragraphs, and } \\
\text { readings. }\end{array}$ \\
\hline 5 & $\begin{array}{l}\text { Topics and } \\
\text { main ideas }\end{array}$ & $\begin{array}{l}\text { Identifying topics and } \\
\text { main ideas. Use of } \\
\text { scanning and skimming } \\
\text { to interact with the text. }\end{array}$ \\
\hline 6 & Text organization & $\begin{array}{l}\text { Recognizing patterns: } \\
\text { cause and effect, } \\
\text { comparison and } \\
\text { contrast, listing, } \\
\text { time order. }\end{array}$ \\
\hline
\end{tabular}

Source: Own elaboration.

\section{Pedagogical intervention}

The teacher began his pedagogical intervention creating awareness with the structure of the reading and the organization of the dictionary, starting from the simple reading strategies to the most complex ones, and the real need to use the dictionary. The teacher modeled how to apply a reading strategy as a way to exemplify it, and each strategy took about two sessions of classes to be covered. Also, the teacher reviewed the topics while working with the readings and assigned workshops every two strategies. 
He guided the students with the following ideas regarding reading strategies and dictionary use:

\section{Reading strategies}

The teacher began his pedagogical intervention analyzing titles and subtitles as they give valuable information concerning the reading students are about to read, leading to prediction. He also asked students to pay attention to true and false cognates, as they help readers identify words. Moreover, the teacher asked students to analyze words by their formations (affixes) because prefixes and suffixes guide them to understand words. Regarding the grammar part, he worked with verbal tenses, sentence structure, basic and complex sentence structure, comparison and superlatives, modal verbs, and possessives. All this grammar part was in context and supported in readings. The teacher also used the following concepts as well as ideas in his pedagogical intervention:

- Scanning: it means to look for specific information. The teacher advised students that they did not have to read or understand every word in a text when they had to answer specific information.

- Topic: a topic tells what is the subject of the reading or the paragraph. The teacher guided the students to look for the topic when they read. He also asked readers to pay attention to high-frequency words. The strategy to observe if some words appear frequently may help readers have an idea of the topic being developed (Mikulecky and Jeffries, 2004).

- Main ideas: the teacher guided the readers to recognize where the main parts of the readings were. He explained that in academic texts the main ideas are usually given at the beginning of each paragraph and they contain the general idea of the passage as well as the whole reading.

- Connectors: or transition words help students identify if a sentence is a central point or a supporting idea. The teacher described that these words help readers connect the ideas that are presented in the text.
- Referents: the teacher explained to the students that writers usually do not like the idea of using the same word repeatedly and they use referents to avoid repetition. The most common words used as referents are pronouns, and they are quite used in readings.

- Pre, while and post-reading activities: these activities help learners activate background knowledge, identify some specific information regarding the message of the reading, and prompt reflection and discussion.

- Application: the teacher highlighted when and where to use a reading strategy. He used some repair strategies such as guessing word meaning, finding the most relevant information in the text, continuing to read until the meaning becomes clear, re-reading difficult parts of the text and trying to connect them to it.

\section{Dictionary use}

The teacher prepared the language learners and followed Nation (2001, p. 284-287) to train readers with the dictionaries:

- Evaluating the need to look up the word: the reader decides if it is necessary to look up the word in the dictionary

- Finding the entry: the reader finds the right word in the dictionary

- Reading the entry: the reader chooses the right entry of the word

- Relating the meaning into the context: the reader verifies if the meaning chosen in the dictionary fits into the context of the reading

- Changing the word into its basic form: the reader uses his/her knowledge of the language to get information about the grammar part of the word

- Guessing: the reader guesses the general meaning of the word in the context

The teacher also covered other activities that included spelling, register, collocation, meaning, antonyms/synonyms, pronunciation, and parts of speech. 


\section{Data analysis and findings}

Data analysis showed that students were more skillful reading in a foreign language after the pedagogical intervention:

\section{Reading comprehension tests}

Although the first and second tests were different, they kept the same structure and level of difficulty. Both trials had two paragraphs and 18 questions each. Table 2 presents the results of all students:

Table 2. Tests results

\begin{tabular}{|c|c|c|c|}
\hline Student & $\begin{array}{c}\text { Right } \\
\text { answers } \\
\text { test } 1\end{array}$ & $\begin{array}{c}\text { Right } \\
\text { answers } \\
\text { test } 2\end{array}$ & Analysis/ comments \\
\hline 1 & 15 & $\begin{array}{l}16 \text { right } \\
\text { answers }\end{array}$ & Improved \\
\hline 2 & 13 & 13 & Remained the same \\
\hline 3 & 13 & 14 & Improved \\
\hline 4 & 14 & 16 & Improved \\
\hline 5 & 16 & 15 & Decreased \\
\hline 6 & 14 & 14 & Remained the same \\
\hline 7 & 12 & 11 & Decreased \\
\hline 8 & 8 & 13 & Improved \\
\hline 9 & 14 & 15 & Improved \\
\hline 10 & 14 & 14 & Remained the same \\
\hline 11 & 12 & 13 & Improved \\
\hline 12 & 8 & 10 & Improved \\
\hline 13 & 7 & 13 & Improved \\
\hline 14 & 8 & 12 & Improved \\
\hline 15 & 14 & 16 & Improved \\
\hline
\end{tabular}

Source: Own elaboration.

Based on the table it can be stated that the overall average score of evaluation increased as 10 students improved, 3 students remained the same and 2 students decreased. This may mean that the pedagogical intervention had a positive effect on students. More specifically, students 8,13 and 14 showed better improvement than the other ones (increased between 4 and 5 points), as they always attended the course, participated in all activities and were quite motivated to do any activity. It is worth noting that their participation and motivation were observed by the teacher and registered on the field notes. The teacher also made notes regarding students' performance and the use of dictionaries during the tests. In the first test, 4 students used their cell phones to find the meaning of some words. 3 students also used their cell phones to translate some lines in the Google translator. 3 students used their bilingual paper dictionaries and wrote the translations of some words as well as some lines on the test, and it is relevant to mention that some translations were inaccurate, and precision was missing. 2 students did not use their paper dictionaries quite often and only used them to find the meaning of a few words. 3 students began translating the readings on the test but did not finish doing them. Regarding time, 1 student took 65 minutes to complete the test, the second 75 minutes, the third one 78 minutes. 9 students took 90 minutes, and students 8,13 and 14 (3 students) did not finish completing the whole test.

In the second test, all students completed it and were faster than the first one. 2 students took 35 minutes to finish the test, 3 students 45 minutes, 1 student 50 minutes, 4 students 60 minutes, 2 students 70 minutes, and 3 students 80 minutes. Besides, students did not use the dictionaries or translators as much as the first test: they just used them to find some words and did not translate lines. Regarding students 8,13 and 14 they finished the full test and did not use the dictionary so much to interact with the readings.

\section{Field notes}

The teacher took notes of each class (38 sessions) and registered some of the strategies students used during the reading comprehension course. After the explanation of each strategy (i.e., cognates, scanning, guessing word meaning, predicting, topic) the teacher gave students lots of material to practice each item not only in the classroom but also as homework. In the classroom, some students did the activities in groups, but the teacher sometimes asked students to do them individually to prompt direct interaction with readings. At the beginning of the course, most students wanted to understand word by word to have a complete idea of the text. In fact, the teacher 
asked student 13 why she wrote the meanings of many words in some readings, and she reported it was essential to understand all details the readings provided. However, this lessened during the course, as students used some reading strategies to understand the texts: previewing, predicting, scanning, guessing, or using portions of relevant information. Some students sometimes showed an awareness of knowledge cognition (Carrell, 1998), because they guided themselves to prepare the reading: first the title and subtitles, then the images and numbers; the first sentence of each paragraph; cognates and affixes. Students also wrote the meanings above each word on the text in Spanish but sometimes the translations were not accurate during the first-class sessions, and they lacked precision or the central points of the readings as reported by Prichard (2008). When students had both the paper dictionary and the cell phones, they rather preferred to use their phones to find the definitions of words. The WordReference.com and the Google translator were the main tools to find the meanings of words as well as to complete ideas for translation.

Next, the teacher began to teach how to use the dictionaries and followed the guide published by Nation (2001): He asked students if it was essential to look up a word in a dictionary, as the context helps to understand the word. If it was necessary to find the meaning of a word, it was important to read all entries and find the most relevant definition depending on the context of the word in the reading. To check if students took the right definition from their dictionaries, the teacher asked some students to read aloud or interpret the word or the idea of a sentence. The teacher also observed that students sometimes worked in groups (couples or trios) and they checked the right meaning or translation of the unknown words leading to construct meaning. During his observations and notes, the teacher noticed that students were more selective or accurate to find the right meaning of the words and the translations were also more appropriate. In the middle of the course, he observed that students did not write the meanings of some words and the use of dictionaries had lessened. Moreover, he noticed that students 8,13 and 14 were more accurate with the answers to the exercises. Student 13 told the teacher that she felt more confident when reading in a foreign language and student 8 agreed. Finally, the teacher concluded that the pedagogical intervention had a positive effect on students due to the analysis of his field notes.

\section{Interviews}

The teacher interviewed each student at the end of the course and asked them about the use of reading strategies, the use of the dictionary, and the positive and negative aspects during the course. Four main categories emerged from the analysis:

1. Metacognitive awareness: since the teacher insisted on verifying understanding while reading, 9 students mentioned that they applied a repetitive frame when reading: "First, I have to check the titles and subtitles, pay attention to the images as well as cognates" (student 1). "I have to read carefully the first and last paragraphs because they contain the introduction and the conclusions of the readings" (student 14).

2. Selective use of the dictionary: 10 students mentioned that they read carefully the different meanings of the words in the dictionary, and they took the most appropriate one based on the context of the reading: "When I have to use the dictionary I do not trust the first definition of a word" (student 11). "Now, I pay attention to the different meanings of a word and I take the best option based on the reading” (student 4). Regarding the Google translator, 4 students mentioned that they sometimes had to check the translations and verify the meaning of some words, as this tool was not quite reliable: "The translation of some words was quite weird" (student 3 ). "I had to use the paper dictionary to check some words as the translation was not quite logical" (student 15).

3. Improvement in reading in a foreign language: all students (15) agreed that they had improved with the reading course. They expressed that 
they were more skillful at interacting with readings, and their speed in reading was better: "I think I am faster when I read in English as a result of this course" (student 9). "When I read English materials in other subjects I apply the strategies that learnt in this course and I have to tell that I am more skillful and understand more the readings" (student 2 ).

4. Tiredness: 7 students expressed that they were sometimes tired because they had to read and do many reading exercises not only in class, but also as part of homework: "Although I am more skillful and have learnt a lot in this course, I sometimes felt tired with the vast majority of readings and exercises my classmates and I had to do" (student 8). "I think a good aspect to take into account is to reduce the amount of readings as well as exercises in the course" (student 12).

\section{Conclusions}

This article has reported a pedagogical experience in reading in a foreign language course. As an answer to the research question about the effects of reading strategy and dictionary instruction in an undergraduate foreign language reading comprehension group include metacognitive awareness, selective use of dictionary, and improvement in reading. As a conclusion, it can be said that both the reading strategy approach and the selective use of dictionary are a good combination to integrate into a foreign language reading course to support improvement. As shown in other studies (Arismendi, Colorado, and Grajales, 2011; Block, 1986; Carrell, 1998; Lopera, 2012; Mikulecky and Jeffries, 2004; Poole, 2009), the explicit inclusion of reading strategy instruction is beneficial for students. A question may arise when to use the dictionary as the application of reading strategies can help avoid using the dictionary. The suggestion includes that the reading strategy approach has to be first as it involves both cognitive and metacognitive processes. This approach guides language learners to handle difficult situations when they read. Once students have applied a reading strategy, they have to decide if it is vital to look up the words they do not know in the dictionary. The use of a dictionary, then, becomes a complementary option in the process of reading. It is worth mentioning that the use of a dictionary must be selective, as some words are not relevant to the main points of the text. When students cannot guess words from the context, and they verify that these words are essential in the reading, they have to look them up in their dictionaries. It is relevant to consider that students can use both printed and electronic dictionaries to apply this strategy.

\section{Limitation}

Some students used the Google translator to understand the readings, but the teacher did not guide them to use it. Future research should include specific guidance to use online translators as an educational tool to accompany the learning process in languages.

\section{References}

Aebersold, J., and Field, M. (1997). From reader to reading teacher. Cambridge: Cambridge University Press.

Al-Musawi, N. M. (2014). Strategic use of translation in learning English as a Foreign Language (EFL) among Bahrain university students. Innovative Teaching, 3 (4). DOI 10.2466/10.03.IT.3.4

Arismendi, F., Colorado, D., and Grajales, L. (2011). Reading comprehension in face-to-face and webbased modalities: graduate students' use of reading and language learning strategies in EFL. Colombian Applied Linguistics Journal, 13 (2), 11-28.

Barnett, M. (1988). Reading through context: How real and perceived strategy affects $\mathrm{L} 2$ comprehension. The Modern Language Journal, 72 (2), 150-162.

Bensoussan, M., Sim, D., and Weiss, R. (1984). The effect of dictionary usage on EFL test performance compared with student and teacher attitudes and expectations. Reading in a Foreign Language, 2, 262-276.

Blake, R. (2008). Brave new digital classroom: Technology and foreign language learning. Washington, DC: Georgetown University Press. 
Block, E. (1986). The comprehension strategies of second language readers. TESOL Quarterly, 20 (3), 63-490.

Bogaards, P. (1998). Using dictionaries: Which words are looked up by foreign language learners? In B. T. S. Atkins and K. Varantola (Eds.), Studies of dictionary use by language learners and translators (pp. 151-157). Tubingen, Germany: Niemeyer.

Cárdenas-Claros, M., and Gruba, P. (2009). Help options in CALL: A systematic review. CALICO Journal, 27 (1), 69-90.

Carrell, P. (1998). Can reading strategies be successfully taught? ARAL, 21 (1), 1-20.

Carrell, P., Pharis, B., and Liberto, J. (1989). Metacognitive strategy training for ESL reading. TESOL Quarterly, $23,647-678$.

Chen, Y. (2012). Dictionary use and vocabulary learning in the context of reading. International Journal of Lexicography, 25 (2), 216-247.

Cohen, A. (1990). Language learning: Insights for learners, teachers, and researchers. Boston: Heinle \& Heinle.

Cook, G. (2010). Translation in language teaching. Oxford: Oxford University Press.

Creswell, J. W. (2007). Qualitative inquiry and research design. Choosing among five approaches. Thousand Oaks: SAGE.

Davis, J. N., and Bistodeau, L. (1993). How do L1 and L2 reading differ? Evidence from think aloud protocols. The Modern Language Journal, 77 (4), 459-471.

Devine, J. (1993). The role of metacognition in second language reading and writing. In J. Carson and I. Leki (Eds.), Reading in the composition classroom: second language perspectives (pp. 105-130). Boston: Heinle \& Heinle.

Flavell, J. H. (1981). Cognitive monitoring. In W. P. Dickson (Ed.), Children's oral communication skills (pp. 35-60). New York: Academic Press.

Freeman, D. (1998). Doing teacher research: From inquiry to understanding. Boston: Newbury House.

Grabe, W., and Stoller, F. (2002). Teaching and researching reading. England: Pearson Education.

Grabe, W., and Stoller, F. (2004). Reading for academic purposes: Guidelines for the ESL/EFL teacher. In M. Celce-Murcia (Ed.), Teaching English as a second or foreign language (pp. 87-204). Boston: Heinle \& Heinle.

Hunt, A. (2009). Dictionaries and vocabulary learning: the roles of $L 1$ and $L 2$ information. Retrieved from nsai-u. ac.jp/fl/publication/pdf_department/01/Hunt.pdf
Jin, L. and Deifell, E. (2013). Foreign language learners' use and perception of online dictionaries: A survey study. MERLOT Journal of Online Learning and Teaching, 9 (4), 515-533.

Knight, S. (1994). Dictionary use while reading: The effects on comprehension and vocabulary acquisition for students of different verbal abilities. The Modern Language Journal, 78, 285-299.

Koyama, T., and Takeuchi, O. (2004). How look up frequency affects EFL learning: An empirical study on the use of handheld-electronic dictionaries. Paper from Proceedings of the CLasic 2004 conference: current perspectives and future directions in foreing language teaching and learning, Singapore.

Laufer, B., and Hadar, L. (1997). Assessing the effectiveness of monolingual, bilingual and "bilingualised" dictionaries in the comprehension and production of new words. The Modern Language Journal, 81 (2), 189-196.

Laufer, B., and Hill, M. (2000). What lexical information do L2 learners select in a CALL dictionary and how does it affect word retention? Language Learning \& Technology, 3 (2), 58-76.

Liu, L. (2014). The integration of dictionary use strategy training into basic English class. Theory and Practice in Language Studies, 4 (10), 2138-2143.

Lopera, S. (2012). Effects of strategy instruction in an EFL reading comprehension course: a case study. PROFILE Issues in Teachers' Professional Development, 14 (1), 79-89.

Loucky, J. P. (2010). Comparing electronic dictionary functions and use. CALICO Journal, 28 (1), 156-174.

Luppescu, S., and Day, R. (1993). Reading, dictionaries, and vocabulary learning. Language Learning, 43, 263-287.

Mikulecky, B., and Jeffries, L. (2004). Reading power. United States: Pearson, Longman.

Miller, G. A. (1999). On knowing a word. Annual Review of Psychology, 50, 1-19.

Mokhtar, A., Mohd, R., and Omar, M. (2013). the role of dictionary strategy in passive vocabulary knowledge acquisition of Net Generation students. Journal for the Study of English Linguistics, 1 (1), 8-20.

Nation, I. (2001). Learning vocabulary in another language. Cambridge, England: Cambridge University Press. 
Peters, E. (2007). Manipulating L2 learners' online dictionary use and its effect on L2 word retention. Language Learning \& Technology, 11, 36-58.

Poole, A. (2009). The reading strategies used by male and females Colombian university students. PROFILE Issues in Teachers' Professional Development, 11 (1), 29-40.

Prichard, C. (2008). Evaluating L2 reader's vocabulary strategies and dictionary use. Reading in a Foreign Language, 20 (2), 216-231.

Pulido, D. (2007). The relationship between text comprehension and second language incidental vocabulary acquisition: A matter if topic familiarity? Language Learning, 57, 155-199.

Robinson, P. (2003). Attention and memory. In C. Doughty and M. H. Long (Eds.), Handbook of second language acquisition (pp. 631-678). Oxford, England: Blackwell.

Schmitt, N. (1997). Vocabulary learning strategies. In N. Schmitt and M. McCarthy (Eds.), Vocabulary. Description, acquisition, and pedagogy (pp. 199-227). Cambridge: Cambridge University Press.
Shen, Z. (2013). The effects of vocabulary knowledge and dictionary use on EFL reading performance. English Language Teaching, 6 (6), 77-85.

Stockwell, G. (2007). A Review of Technology Choice in Teaching language Skills and Areas in the CALL literature. ReCALL, 19 (2), 105-120.

Summers, D. (1988). The role of dictionaries in language learning. In R. Carter and M. McCarthy (Eds.), Vocabulary and language teaching (pp. 111-125). London: Longman.

Tang, G. (1997). Pocket electronic dictionaries for second language learning: Help or hindrance? TESL Canada Journal, 15, 39-57.

Thornbury, S. (2002). How to teach vocabulary. Harlow: Longman.

Yin, R. K. (2003). Case study research. Design and methods. [3rd ed.]. Thousand Oaks: SAgE. 